\title{
Anti-inflammatory and immune modulatory properties of mesenchymal stromal cells
}

\author{
Willem E Fibbe
}

From 6th European Workshop on Immune-Mediated Inflammatory Diseases

Nice, France. 23-25 November 2011

\section{Abstract not submitted for publication}

Published: 23 November 2011

doi:10.1186/1479-5876-9-S2-115

Cite this article as: Fibbe: Anti-inflammatory and immune modulatory

properties of mesenchymal stromal cells. Journal of Translational Medicine

2011 9(Suppl 2):115.

Submit your next manuscript to BioMed Central and take full advantage of:

- Convenient online submission

- Thorough peer review

- No space constraints or color figure charges

- Immediate publication on acceptance

- Inclusion in PubMed, CAS, Scopus and Google Scholar

- Research which is freely available for redistribution 